\title{
Stream Sediments Geochemical Exploration in Wadi El Reddah area, Northeastern Desert, Egypt
}

\author{
Hamed Mira, Hussein Hussein, Sameh Tawfik * and Neveen Abed \\ Nuclear Materials Authority, P.O. Box: 530 Maadi, Cairo, Egypt
}

\begin{abstract}
Wadi El Reddah representing a semi-closed basin, extends in the N-S direction. It has only one outlet at the northern tip while the wadi collects floodwater from internal tributaries along wall rocks. The present study discusses the relationship between geology and geochemistry data to detect anomalous radioactive locations. The geochemical maps show the mineralization areas with abnormal rare metal contents. This led to two uranium occurrences (GXXIII and GXXIV) at Gabal Gattar in the perthitic leucogranite. At Wadi El Reddah, high contents of pathfinder elements (REE, Y, Zn, Nb and As) were discovered at the southern and eastern boundaries. This may be attributed to the presence of alkali feldspar granite at Gabal Gattar at the upstream of Wadi El Reddah and also to the sharp contact between Gabal Gattar and Hammamat Sedimentary rocks. A strong positive correlation coefficient between $\mathrm{Fe}_{2} \mathrm{O}^{\mathrm{t}}$ and or $\mathrm{Al}_{2} \mathrm{O}_{3}$ with $\mathrm{Zr}$, Hf, Nb, Ta, REE, U, Rb, and Th reflects their association with thematization processes.
\end{abstract}

Keywords: Wadi El Reddah; Geochemistry; radioactivity; stream sediments.

\section{Introduction}

Exploration geochemistry is ideally valid to search for low grade deposits, especially those, which are difficult to recognize visually. This is attributed to the fact that geochemistry is a direct method that measures the actual indicator elements or compounds being sought to detect an anomaly. Indicator or pathfinder elements are those minerals or elements found in close association with the desired element, which can be more readily found or have more obviously anomalous features than the element that is the main object of search ${ }^{1}$.

Elements tend to be associated because of similar relative mobility in a group of geological processes. Useful pathfinder elements with more desirable geochemical or analytical properties than the principal ore metal being sought. The geochemical survey can also be classified according to sampling media, e.g., stream sediments or soil surveys, water surveys, rock surveys, etc. Stream-sediments survey is used most commonly for reconnaissance survey. Streamsediments survey is conducted by sampling the sediments of drainage basins. If tested correctly, stream sediment is an ideal composite of the drainage basin materials lying upstream from the sample site. Weathering products and rocks upstream from sampling sites are representative at the scale of the drainage basins. The data obtained reflect the presence of anomalies related directly to the leaching and erosion of ore bodies and the geochemical characteristics of the

*Corresponding author: Sameh Tawfik

Email address: samehzakaria@outlook.com

DOI: http://dx.doi.org/10.13171/mjc10802011021539st host rocks, which can be used to identify the setting in which the deposits occur. Sediments in a stream contain elements derived from the surrounding watershed. Their composition is more representative of the area's geochemical characteristics than other less easily available sampling media such as soil, plant, and groundwater. Rainfall and weathering are more extensive, and hence sediment yield is very high in streams of local extent.

The transport of dissolved trace elements in soils depends primarily on their concentration gradient spatially and the water's mass flow. Dissolved trace elements will be more mobile in sandy soils because the diffusive and connective water fluxes tend to be higher than in loams or clay.

Potassium (K), uranium (U), and thorium (Th) are the principal radioactive elements in terrestrial materials. These radioelements occur in a wide variety of minerals in various combinations, commonly as phosphates (monazite), silicates (zircon), and oxides (uraninite). Daughter products of the $\mathrm{U}$ and Th decayseries include radon $(\mathrm{Rn})$ and radium $(\mathrm{Ra})$, whose presence and relative abundance has implications for exposure-related health hazards. Where host minerals occur in unusually high concentration (mineralization; not necessarily a mineral deposit), Rn may be of serious concentration when spatially associated with the human community. Therefore concerns for the effect of these radioactive elements on the environment and human health have increased 
in the last few decades ${ }^{2}$. The importance of Wadi El Reddah area is notably increased in the last few years after the discovery of secondary uranium mineralization in both the stream sediments filling Wadi El Reddah as well as two uranium occurrences, namely GXXIII and GXXIV in the perthitic leucogranite of Gabal Gattar, which gives a clue of the presence of uranium in that sector of Gattar prospect. This study aims to recognize the nature and geochemical behavior of the rare metals in their secondary dispersion aureoles around Wadi El Reddah. Moreover, to throw some light on the relationships between $\mathrm{U}$ mineralization and other rare metals (i.e., Nb, REE, Y, As, Zr, and Th) in the studied stream sediments.

\section{Geological Setting}

Stream sediments remain the favored geochemical sampling media for regional and local mineral exploration programs in most parts of the world. Wadi El Reddah is considered a semi-closed basin where the only open tributary is very narrow. Thick recent wadi sediments generally cover the wadis floor and their tributaries in Gabal Gattar area. These fluvial sediments are unconsolidated and consist of sands, pebbles, gravels, cobbles, and boulders. The thickness of the stream sediments can be estimated from the groundwater wells and ranges from 25 to 30 meters.

The drainage system of Wadi El Reddah reveals the presence of two to three sub-basins along its course; these are the southeastern, central, and northeastern sub-basin. Each of the mentioned sectors collects its streams and floods from different rocks exposed around the semi-circular southern margin of this wadi. This would facilitate prospecting the remote and highly elevated areas, especially in Gattar granites. Wadi El Reddah is truncated northward along the main course of Wadi Bali and is considered as one of its branches draining towards it. Wadi El Reddah is a branch of Wadi Bali and is truncated northward along the main course. Wadi El Reddah is mainly surrounded by metavolcanics and metagabbro-diorite exposures and the long exposure of Hammamat sedimentary rocks, monzogranite of Gabal El Reddah, perthitic leucogranites of Gabal Gattar, and post-granitic dyke swarms. Figure 1 shows the sampling sites along with the drainage system of Wadi El Reddah.

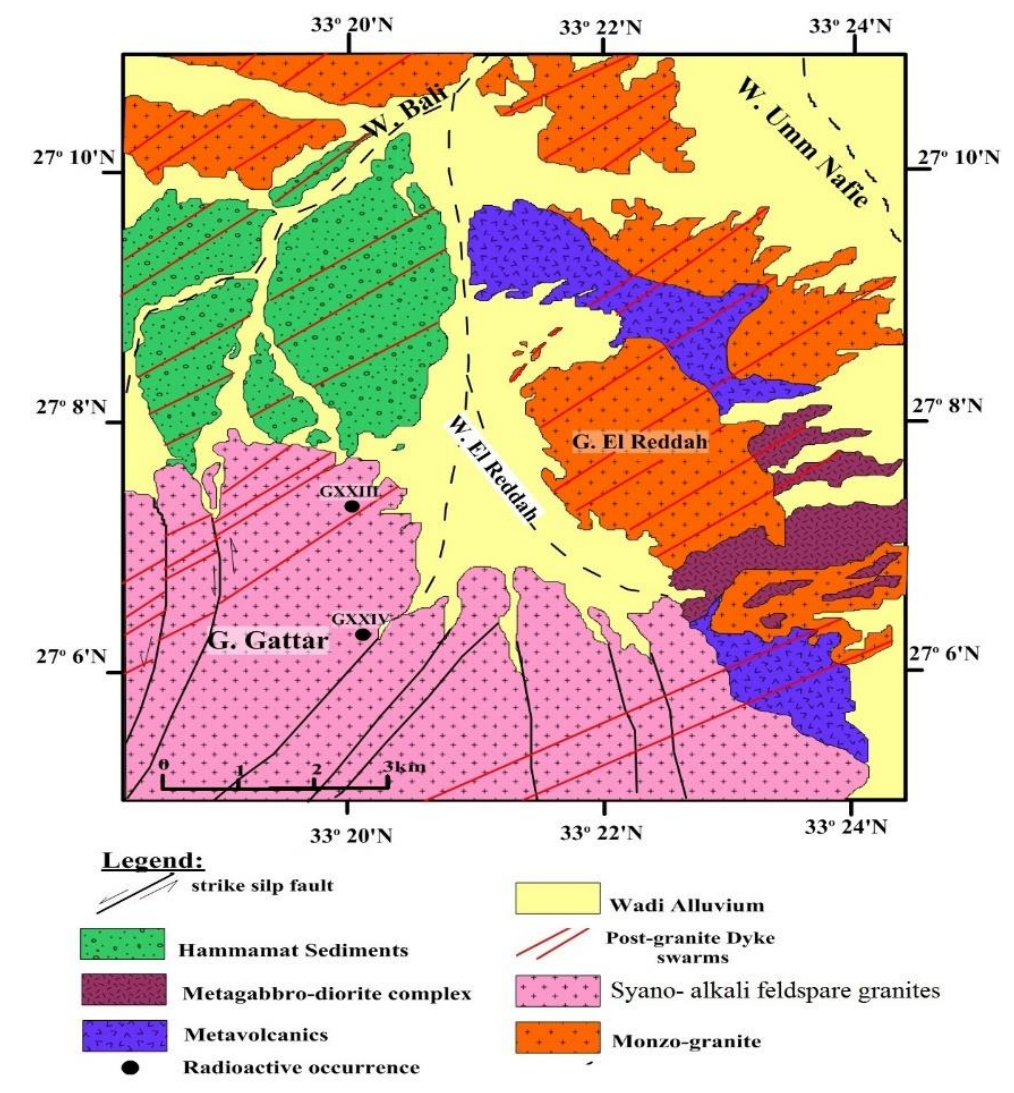

Figure 1. Geological map of Wadi El Reddah area, North Eastern Desert ${ }^{3}$

\section{II.1. Methodology}

Forty-one stream sediment samples were collected from W. El Reddah (Figure 2) using a rock-cutter and a shovel to dig holes at different depths ranging from 90 to $230 \mathrm{~cm}$. Each sample $(-7 \mathrm{Kg})$ was sieved to obtain fractions of sand to clay. Ten stream sediment representative samples were assayed for major oxides, trace, and rare earth elements using the Inductively Coupled Plasma Emission Spectrometry (ICP-ES) and ICP-Mass Spectrometry (ICP-MS) at ACME Analytical Laboratories, Vancouver, Canada.

\section{II.2. Geochemical mapping}

Table 1 shows the trace element contents of the stream 
sediment samples. Figures (3a-3) represents the geochemical maps for the trace elements. It is noticed that Wadi El Reddah has anomalous concentrations of pathfinder elements at the eastern and southern parts compared with the published background values ${ }^{4}$, (Table 2). This might be attributed to the sharp contact between Gabal Gattar and the Hammamat sediments and the presence of alkali feldspar granite of Gabal Gattar at the upstream of the study area heavy resisting minerals such as zircon, xenotime, thorite, and columbite-tantalite.

Table 1. Wadi El Reddah stream sediments trace element contents.

\begin{tabular}{|c|c|c|c|c|c|c|c|c|c|c|}
\hline \multirow{2}{*}{$\begin{array}{l}\text { Trace } \\
\text { ppm }\end{array}$} & \multicolumn{10}{|c|}{ Stream Sediments } \\
\hline & 1 & 6 & 7 & 11 & 12 & 13 & 16 & 27 & 38 & 40 \\
\hline $\mathrm{Ba}$ & 95 & 90 & 98 & 88 & 115 & 97 & 93 & 125 & 120 & 115 \\
\hline Co & 2.2 & 2.5 & 3.0 & 3.0 & 3.6 & 3.3 & 2.9 & 3.4 & 3.5 & 3.45 \\
\hline Cs & 12.6 & 15.1 & 11.80 & 12.9 & 13.4 & 12.6 & 12.6 & 13.3 & 12.9 & 20.5 \\
\hline $\mathrm{Ga}$ & 40.3 & 55 & 46.87 & 46.1 & 61 & 52.1 & 50.3 & 46.1 & 60 & 59.8 \\
\hline $\mathrm{Hf}$ & 30 & 60 & 32 & 33 & 121.5 & 56 & 43 & 29 & 27.8 & 54 \\
\hline $\mathrm{Nb}$ & 146.1 & 210.3 & 144.2 & 158.1 & 222.4 & 160.8 & 156.3 & 140.3 & 143.8 & 187 \\
\hline $\mathrm{Rb}$ & 250.8 & 273.6 & 246.8 & 255.2 & 257.7 & 261.7 & 260.4 & 246.5 & 261.7 & 305.2 \\
\hline $\mathrm{Sn}$ & 10.3 & 18.9 & 10.3 & 20.3 & 20.6 & 10.3 & 9.9 & 11.3 & 20.8 & 18.3 \\
\hline $\mathrm{Sr}$ & 31.9 & 28.7 & 36.3 & 33.1 & 63 & 44.3 & 31.9 & 69 & 42.3 & 73 \\
\hline $\mathrm{Ta}$ & 14.9 & 35.9 & 10.5 & 10.7 & 30.3 & 10.7 & 15.2 & 10.5 & 15.5 & 30.1 \\
\hline Th & 25.8 & 66.9 & 45.5 & 28.3 & 128 & 24.6 & 39.2 & 20.0 & 23.0 & 50.4 \\
\hline $\mathrm{Tl}$ & 2.2 & 2.3 & 2.0 & 2.3 & 2.2 & 2.3 & 2.29 & 2.24 & 2.3 & 3.1 \\
\hline $\mathrm{U}$ & 249 & 202 & 250 & 296 & 320 & 294 & 255 & 250 & 270 & 300 \\
\hline $\mathrm{V}$ & 10.2 & 10.5 & 19.5 & 10.9 & 37 & 19.7 & 10.2 & 20.1 & 20.1 & 25.3 \\
\hline W & 35 & 98 & 26.8 & 28.9 & 56 & 26.1 & 26.8 & 27 & 28 & 53 \\
\hline $\mathrm{Zr}$ & 300.1 & 600.5 & 315.45 & 330.5 & 1215 & 560 & 295.05 & 270.1 & 278 & 540 \\
\hline Mo & 44 & 62 & 32 & 37 & 60 & 30 & 28 & 45 & 32 & 32.4 \\
\hline $\mathrm{Ag}$ & 0.03 & - & 0.03 & 0.04 & 0.08 & 0.05 & 0.04 & 0.02 & 0.02 & 0.01 \\
\hline $\mathrm{Au}$ & - & - & - & - & - & - & - & - & - & 0.73 \\
\hline $\mathrm{Cu}$ & 59.4 & 65 & 70 & 59.3 & 67 & 65.55 & 66 & 75 & 80 & 74 \\
\hline $\mathrm{Pb}$ & 64.8 & 69.7 & 64.85 & 66.3 & 81.5 & 69.3 & 65.91 & 70.5 & 65.3 & 72 \\
\hline $\mathrm{Zn}$ & 59 & 171.5 & 70.2 & 90.5 & 259 & 239 & 76.15 & 91.5 & 92.3 & 180.3 \\
\hline $\mathrm{Ni}$ & 150 & 208 & 202.1 & 163 & 186.4 & 200.5 & 163 & 170.3 & 190.3 & 170.3 \\
\hline $\mathrm{Bi}$ & 3.9 & 4.1 & 3.1 & 3.9 & 4.6 & 3.4 & 2.5 & 2.5 & 3.5 & 5.3 \\
\hline As & 50 & 93 & 108 & 208 & 130 & 128 & 89 & 70 & 128 & 128 \\
\hline $\mathrm{Cd}$ & 0.21 & 0.19 & 0.2 & 0.19 & 0.2 & 0.2 & 0.22 & 0.23 & 0.22 & 0.18 \\
\hline $\mathrm{Sb}$ & 2.1 & 4.5 & 2.4 & 2.5 & 4.8 & 4.2 & 2.0 & 2.4 & 2.4 & 4.1 \\
\hline $\mathrm{Cr}$ & 11.8 & 12 & 12 & 12.2 & 19 & 15 & 12.2 & 19 & 22 & 18.3 \\
\hline $\mathrm{Be}$ & 10.3 & 10.3 & 10.3 & 8.3 & 10.3 & 9.2 & 10 & 10.5 & 8.3 & 10.3 \\
\hline $\mathrm{Sc}$ & 6.2 & 6.2 & 6.2 & 7.5 & 13.1 & 9.3 & 6.2 & 9.3 & 13 & 13.1 \\
\hline $\mathrm{Li}$ & 57.3 & 79 & 55 & 63 & 85.2 & 86.3 & 60 & 86 & 56 & 75.3 \\
\hline In & 0.08 & 0.09 & 0.09 & 0.1 & 0.2 & 0.1 & 0.05 & 0.15 & 0.08 & 0.2 \\
\hline $\mathrm{Re}$ & 0.02 & 0.02 & 0.02 & 0.02 & 0.03 & 0.02 & 0.02 & 0.02 & 0.02 & 0.02 \\
\hline $\mathrm{Y}$ & 280 & 680 & 360 & 650 & 720 & 660 & 400 & 290 & 390 & 710 \\
\hline
\end{tabular}




\begin{tabular}{|c|c|c|c|c|c|c|c|c|c|c|}
\hline $\mathrm{La}$ & 15 & 24.2 & 15.1 & 20.5 & 44.2 & 20.9 & 18 & 25.3 & 20.8 & 28.3 \\
\hline $\mathrm{Ce}$ & 140.3 & 202.3 & 146.3 & 163.9 & 320 & 168.6 & 180.1 & 169 & 180.9 & 202 \\
\hline $\mathrm{Pr}$ & 7.1 & 11.2 & 7.2 & 11.1 & 20 & 10 & 8.8 & 10.51 & 11.01 & 14.98 \\
\hline $\mathrm{Nd}$ & 63.1 & 95.4 & 65.2 & 82.1 & 160.2 & 80.3 & 70.3 & 80.3 & 88.3 & 90.9 \\
\hline $\mathrm{Sm}$ & 11.9 & 19.2 & 12.2 & 14.3 & 32.4 & 16.6 & 14.4 & 14.4 & 14.8 & 19.2 \\
\hline $\mathrm{Eu}$ & 1 & 0.9 & 1 & 1 & 3 & 2 & 0.8 & 1 & 1 & 2 \\
\hline $\mathrm{Gd}$ & 13.0 & 20.8 & 13.6 & 16.8 & 36.3 & 18.9 & 16.0 & 16.2 & 16.5 & 18.9 \\
\hline $\mathrm{Tb}$ & 2.5 & 4.4 & 3.2 & 3.5 & 8 & 4 & 3.2 & 3.4 & 3.6 & 4 \\
\hline $\mathrm{Dy}$ & 17.0 & 28.8 & 19.2 & 19.8 & 48 & 24.5 & 20.2 & 20.2 & 20.8 & 20.3 \\
\hline $\mathrm{Ho}$ & 3.3 & 6.8 & 5 & 5.3 & 10.6 & 5.3 & 4.9 & 5 & 5.3 & 5.7 \\
\hline $\mathrm{Er}$ & 58 & 102.3 & 63 & 88 & 170 & 85 & 68 & 69 & 83 & 85 \\
\hline $\mathrm{Tm}$ & 1.9 & 3.4 & 2.2 & 2.6 & 5.1 & 2.6 & 2 & 2.2 & 2.7 & 2.8 \\
\hline $\mathrm{Yb}$ & 100 & 170.5 & 118 & 124 & 250 & 125 & 115 & 118 & 124 & 90 \\
\hline $\mathrm{Lu}$ & 4 & 9 & 4.5 & 6 & 10.1 & 5 & 4.5 & 4.5 & 6 & 8 \\
\hline $\mathrm{REE}(\mathrm{T})$ & 438.1 & 699.2 & 475.7 & 546.65 & 1117.9 & 568.7 & 526.2 & 539.01 & 578.71 & 592.0 \\
\hline
\end{tabular}

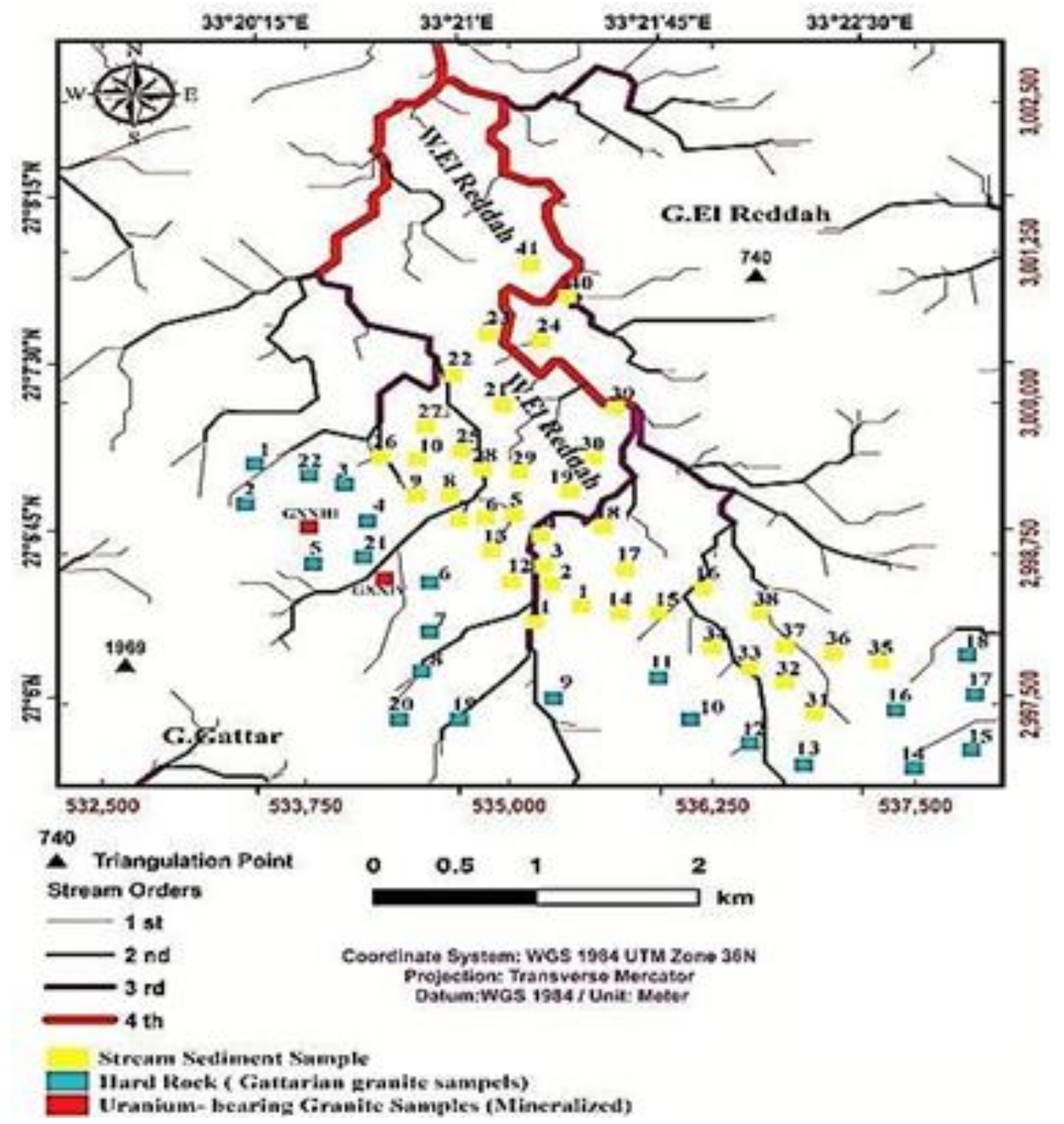

Figure 2. Sampling sites along Wadi El Reddah drainage system map 


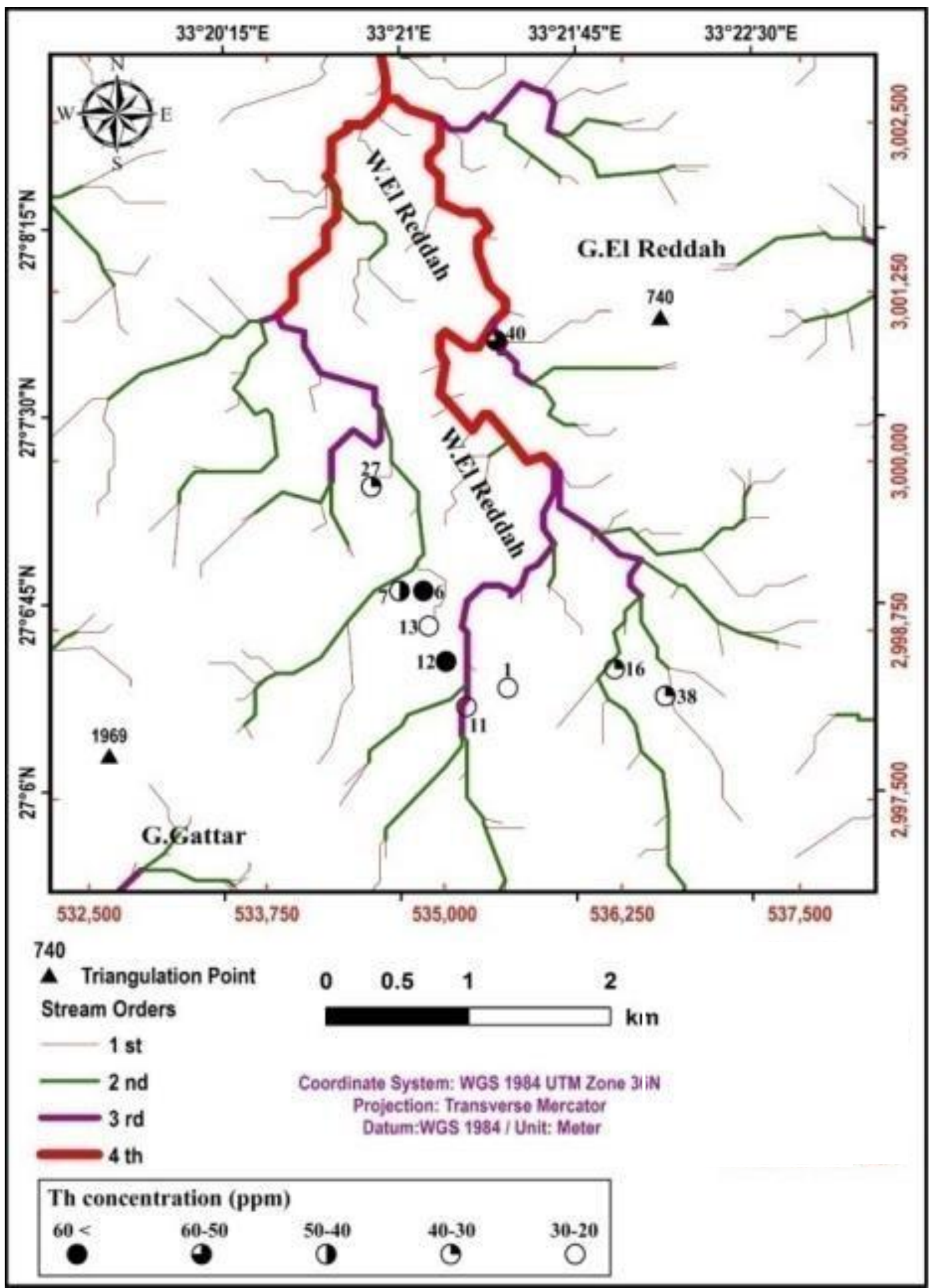

Figure 3a. Geochemical map of Th concentration (ppm) distribution in the stream sediments of Wadi El Reddah 


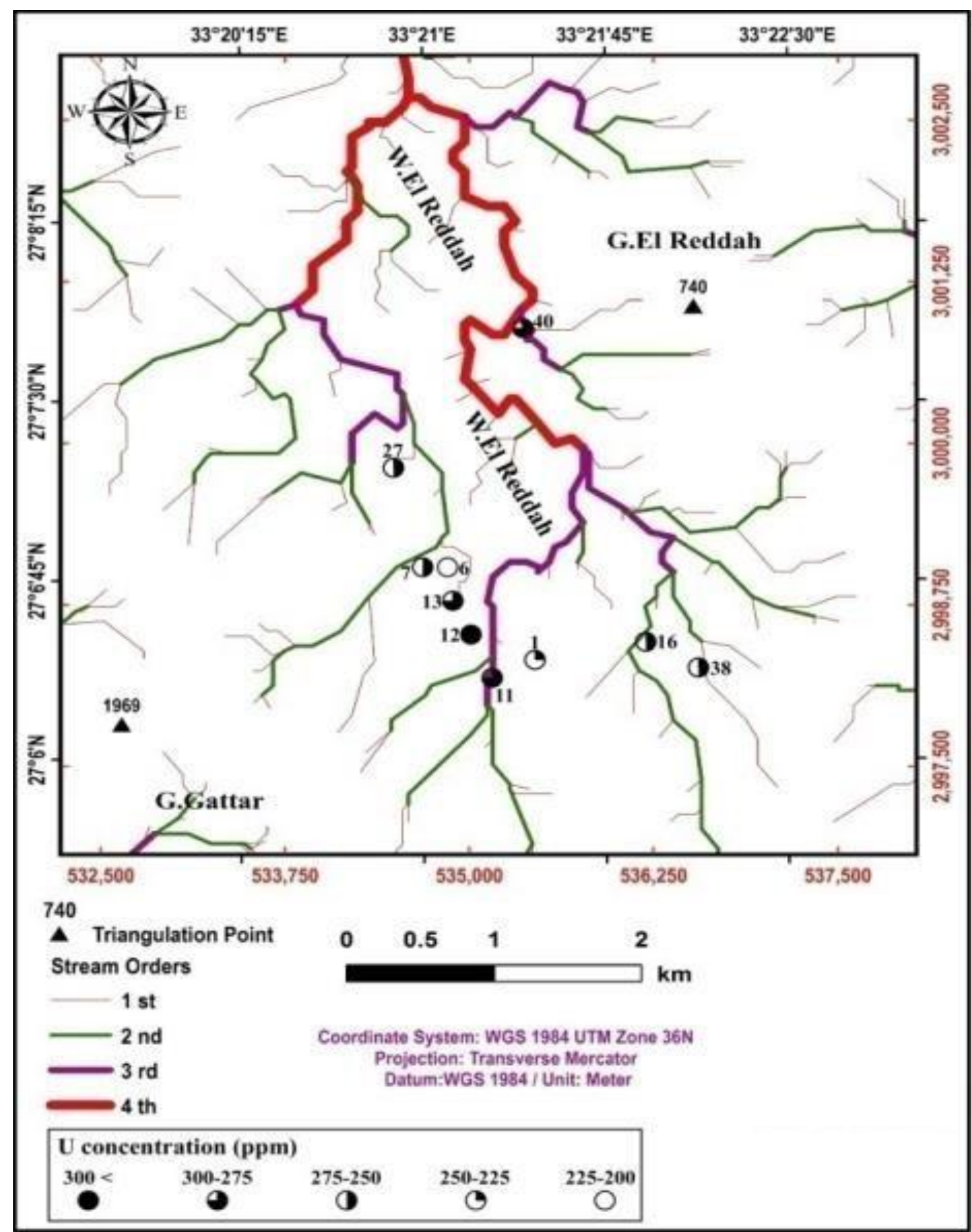

Figure 3b. Geochemical map of U concentration (ppm) distribution in the stream sediments of Wadi El Reddah 


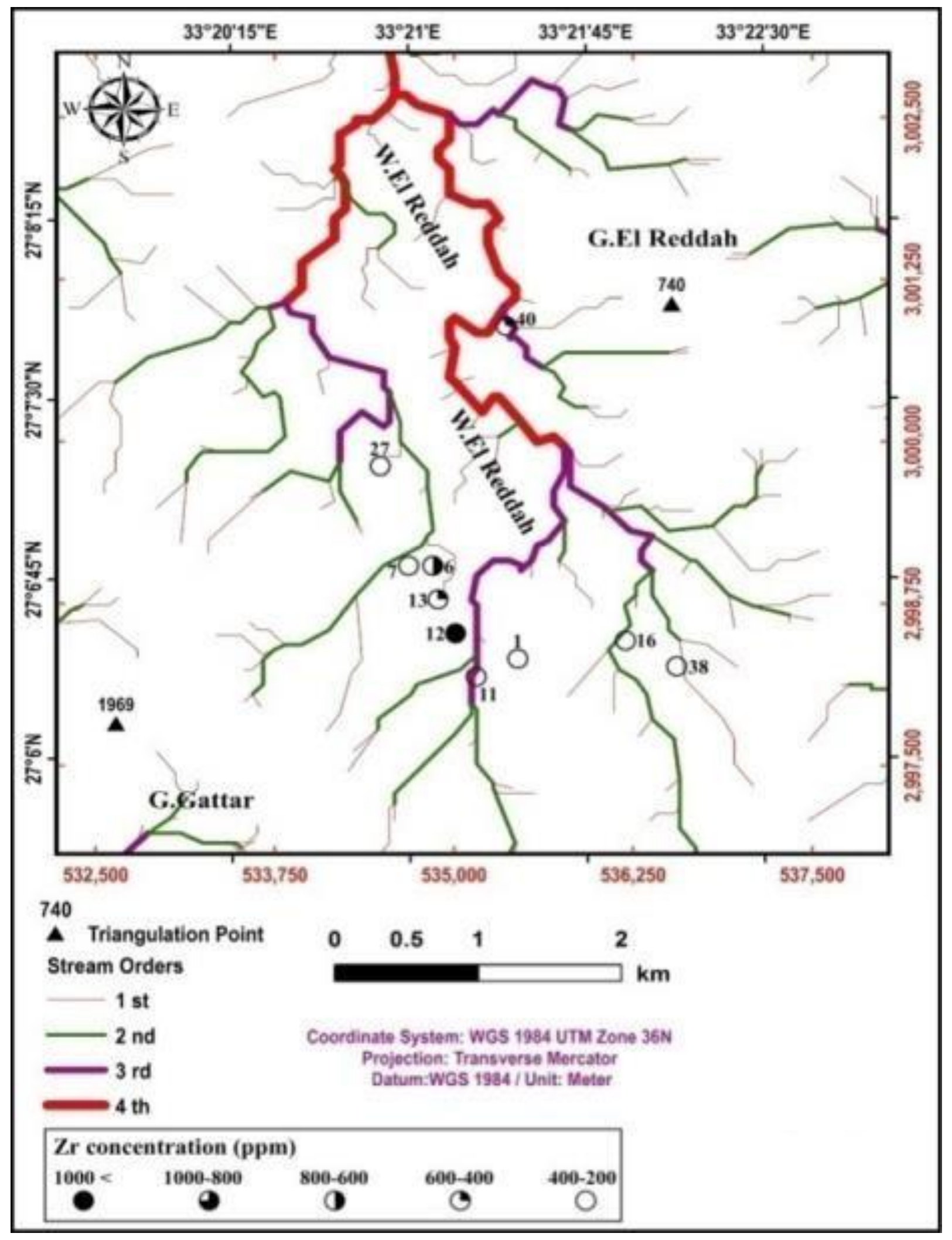

Figure 3c. Geochemical map of $\mathrm{Zr}$ concentration (ppm) distribution in the stream sediments of Wadi El Reddah 


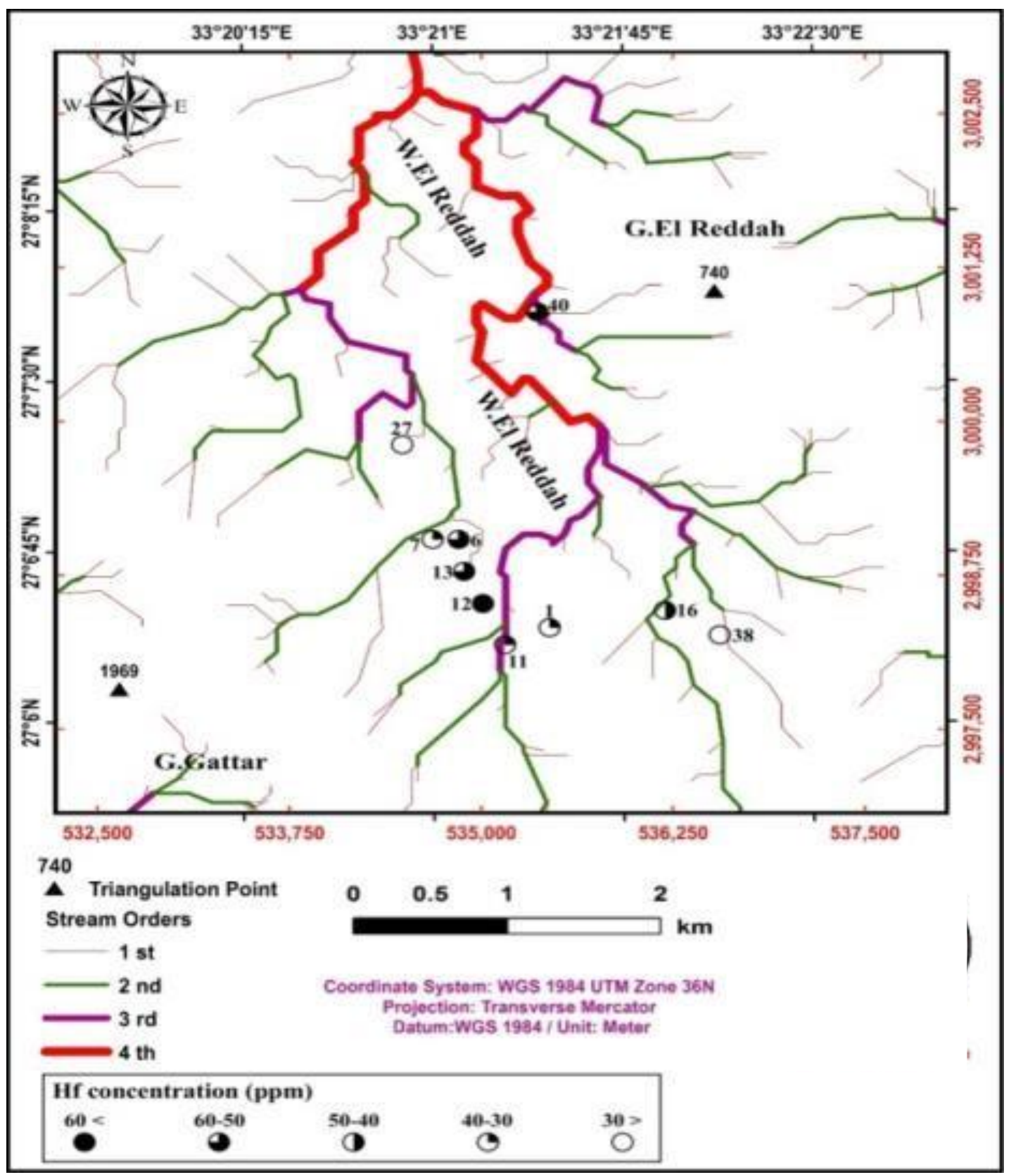

Figure 3d. Geochemical map of Hf concentration (ppm) distribution in the stream sediments of Wadi El Reddah 


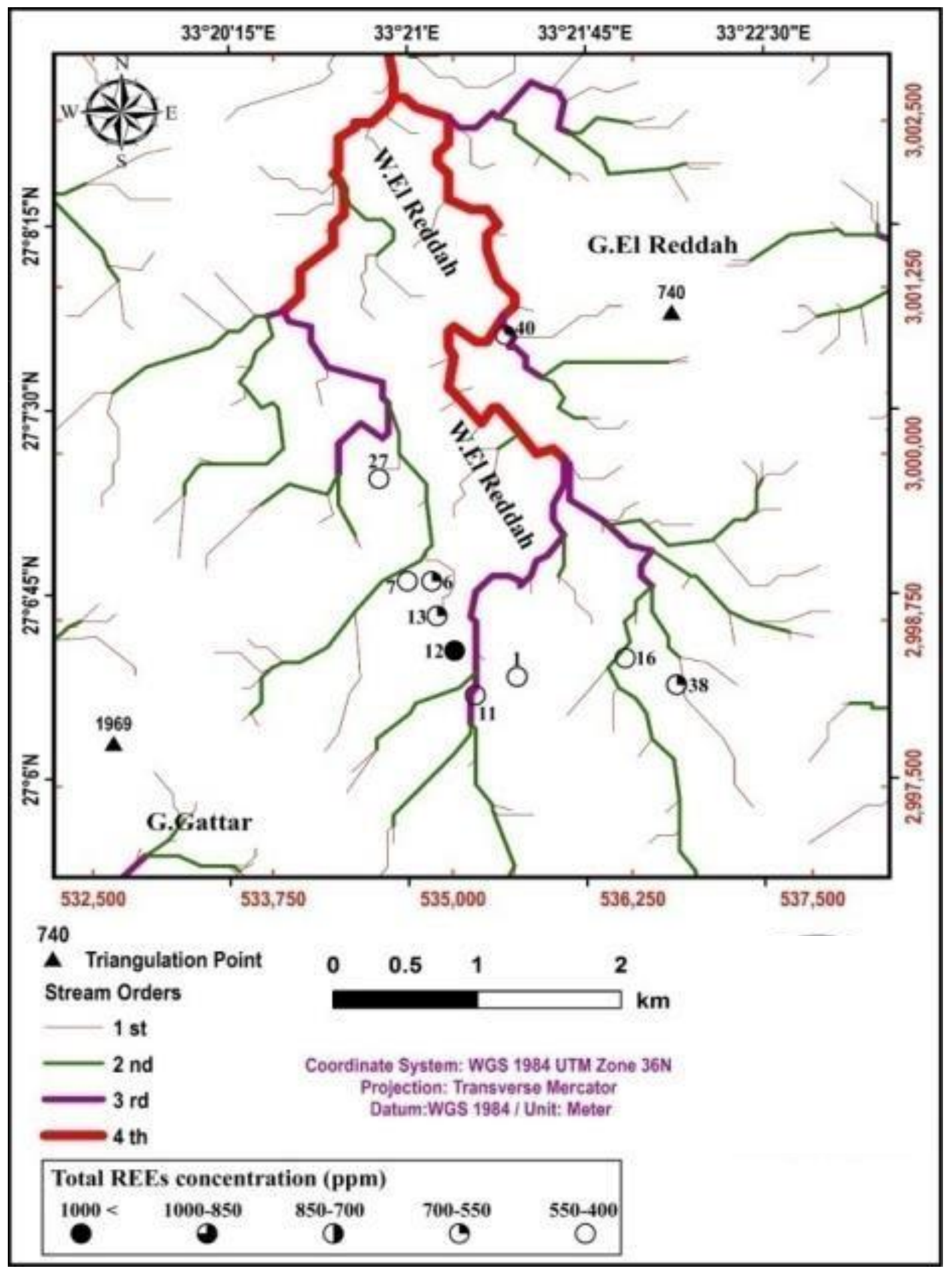

Figure 3e. Geochemical map of The total REEs concentration (ppm) distribution in the stream sediments of Wadi El Reddah 


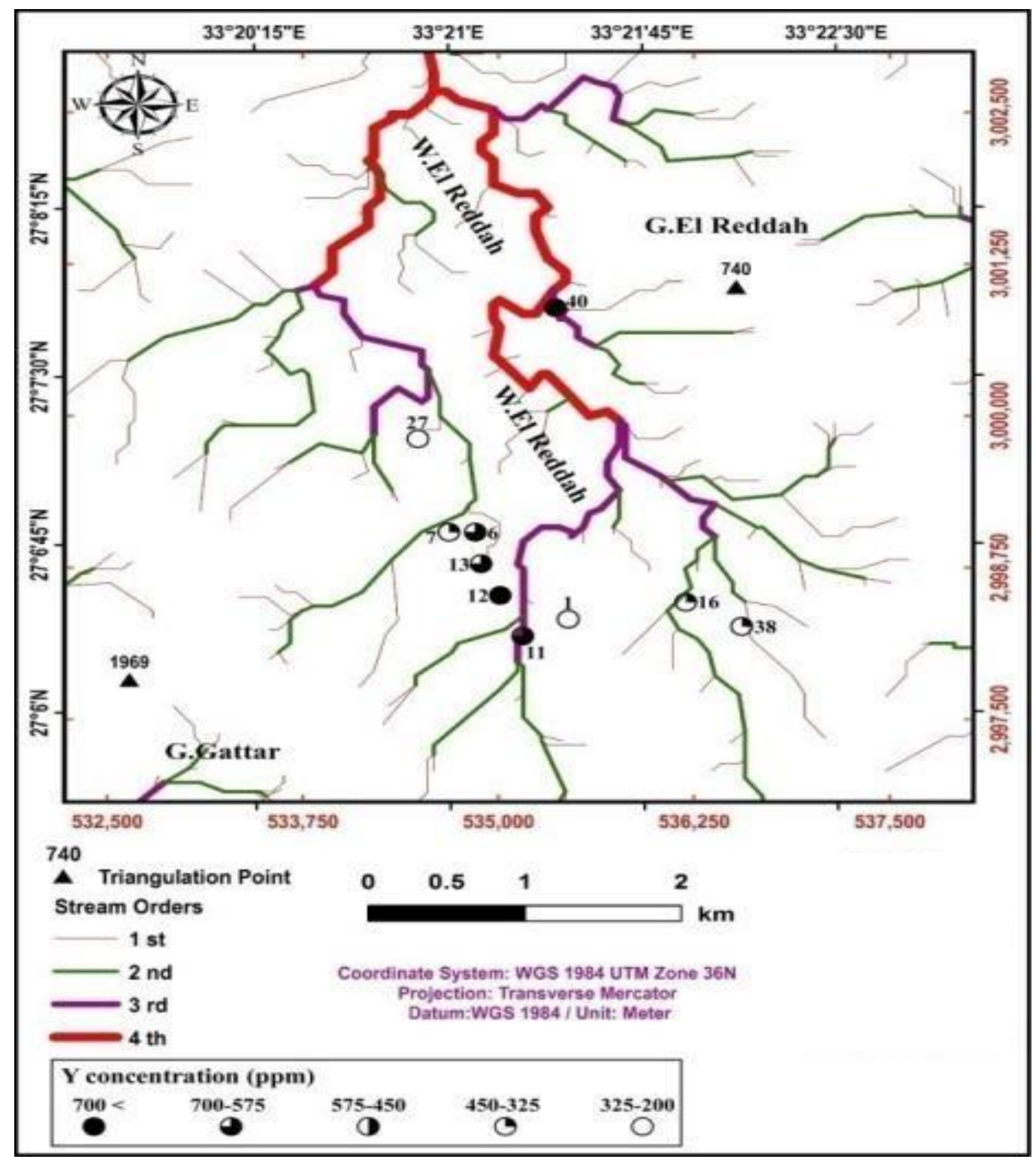

Figure 3f. Geochemical map of $Y$ concentration (ppm) distribution in the stream sediments of Wadi El Reddah 


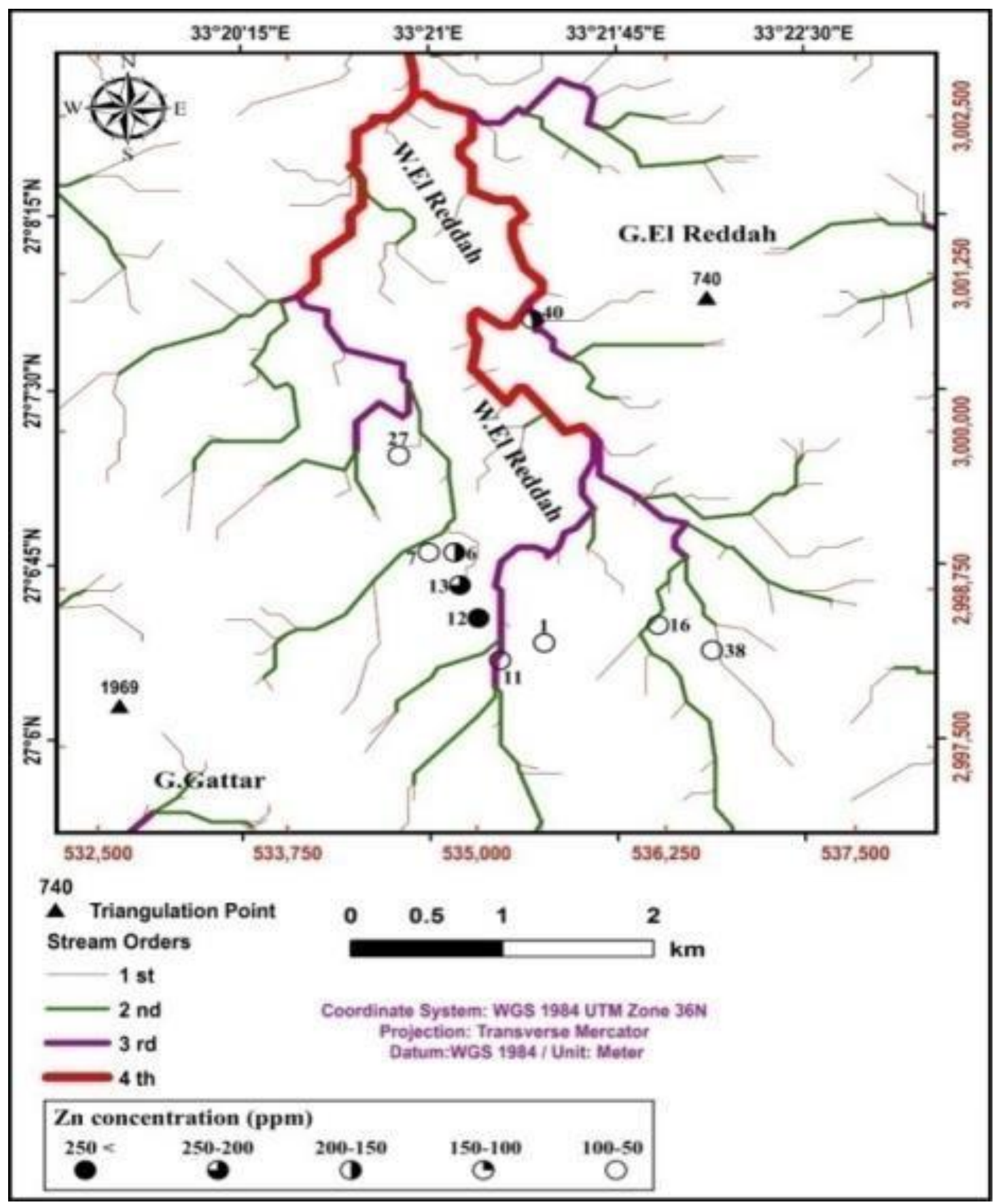

Figure 3g. Geochemical map of $\mathrm{Zr}$ concentration (ppm) distribution in the stream sediments of Wadi El Reddah 


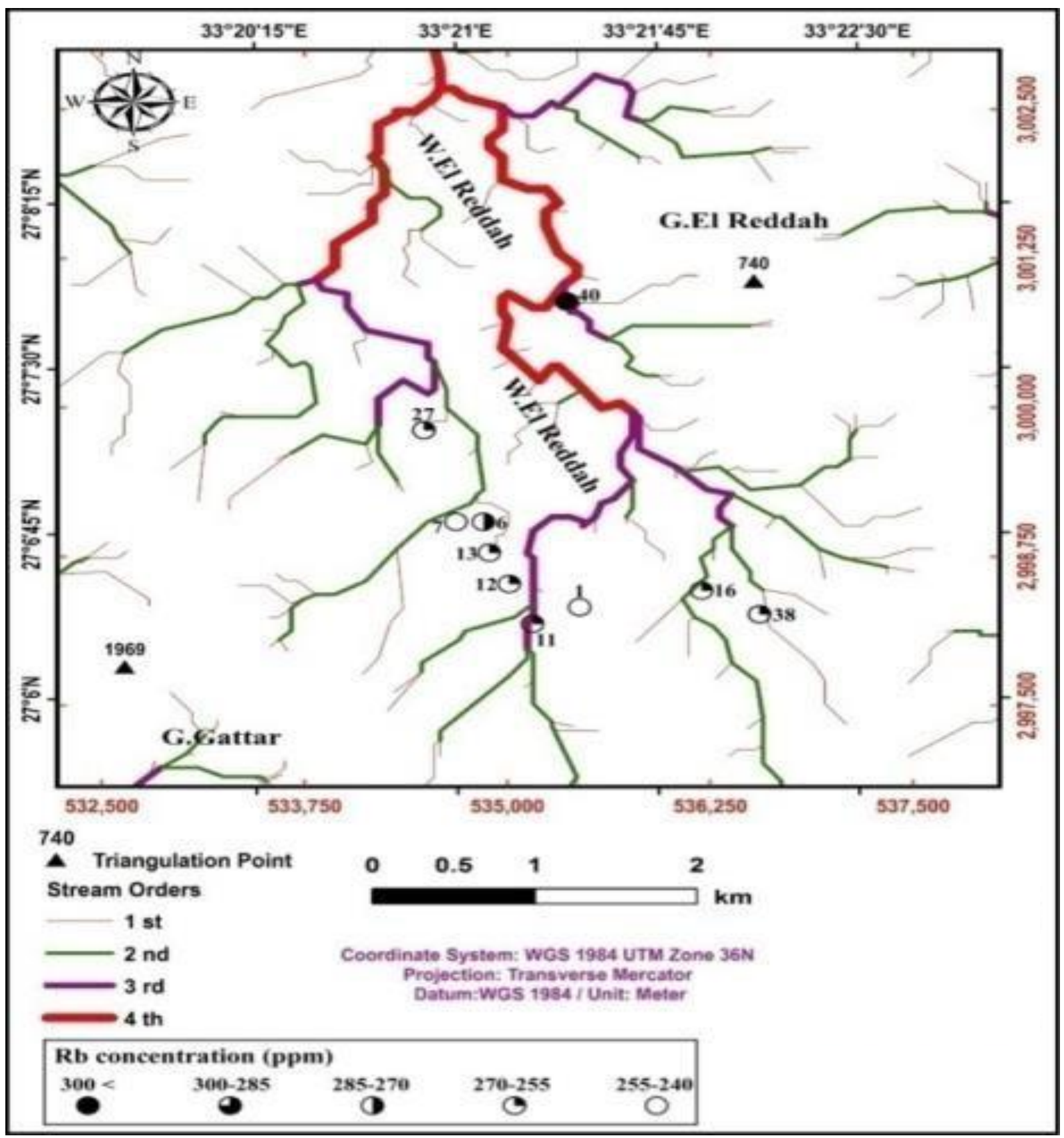

Figure 3h. Geochemical map of Rb concentration (ppm) distribution in the stream sediments of Wadi El Reddah 


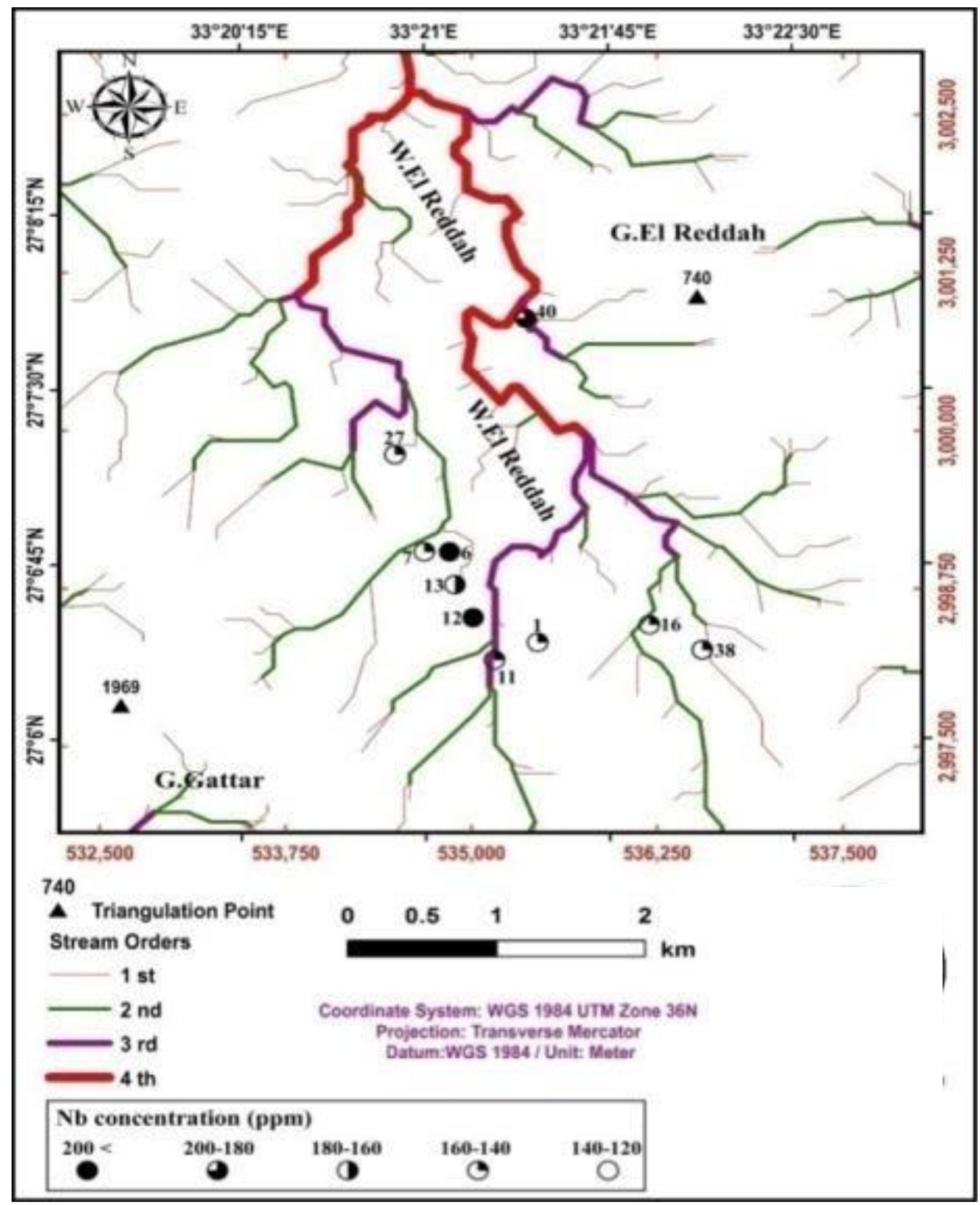

Figure 3i. Geochemical map of $\mathrm{Nb}$ concentration (ppm) distribution in the stream sediments of Wadi El Reddah 


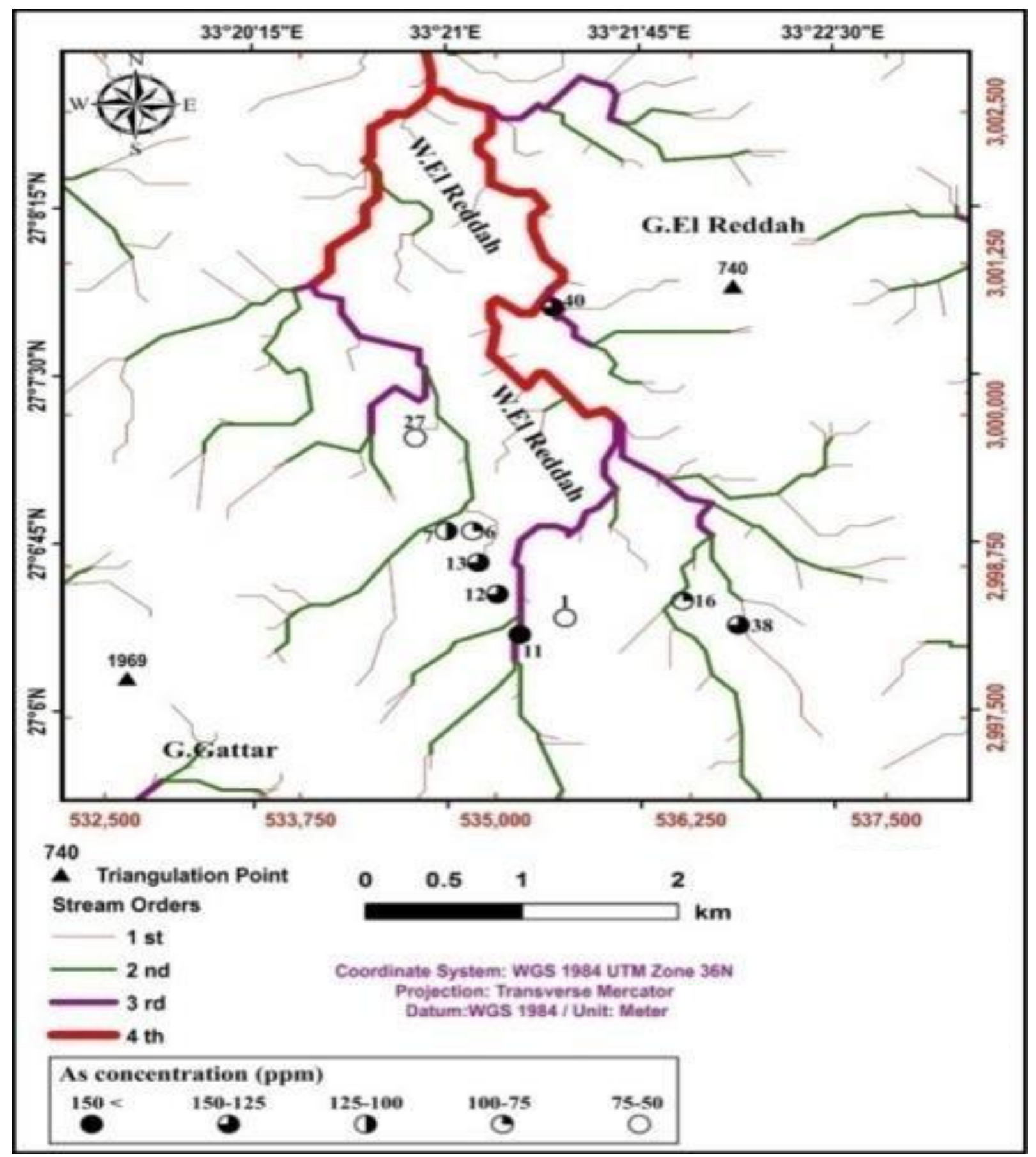

Figure 3j. Geochemical map of As concentration (ppm) distribution in the stream sediments of Wadi El Reddah 


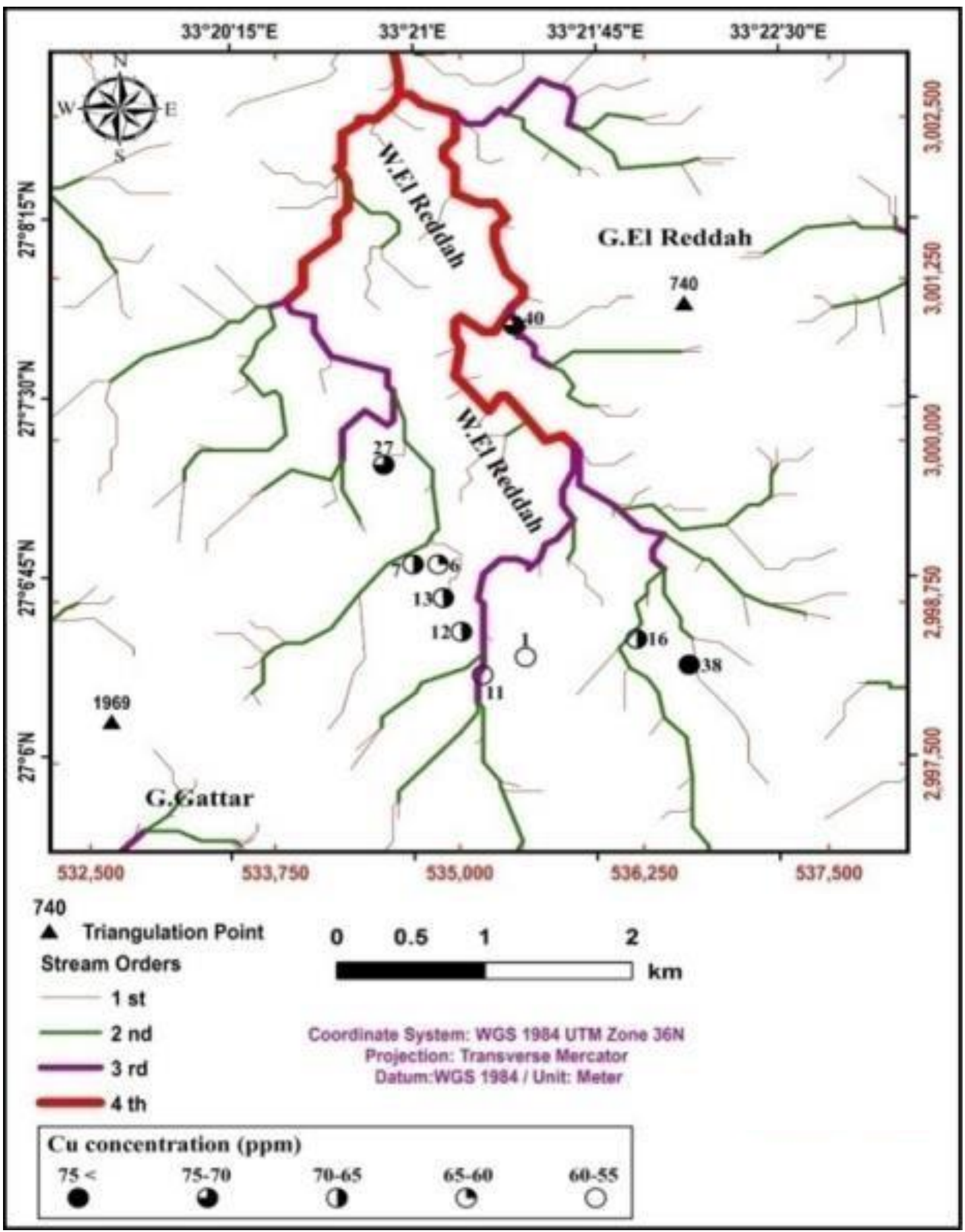

Figure 3k. Geochemical map of $\mathrm{Cu}$ concentration (ppm) distribution in the stream sediments of Wadi El Reddah 


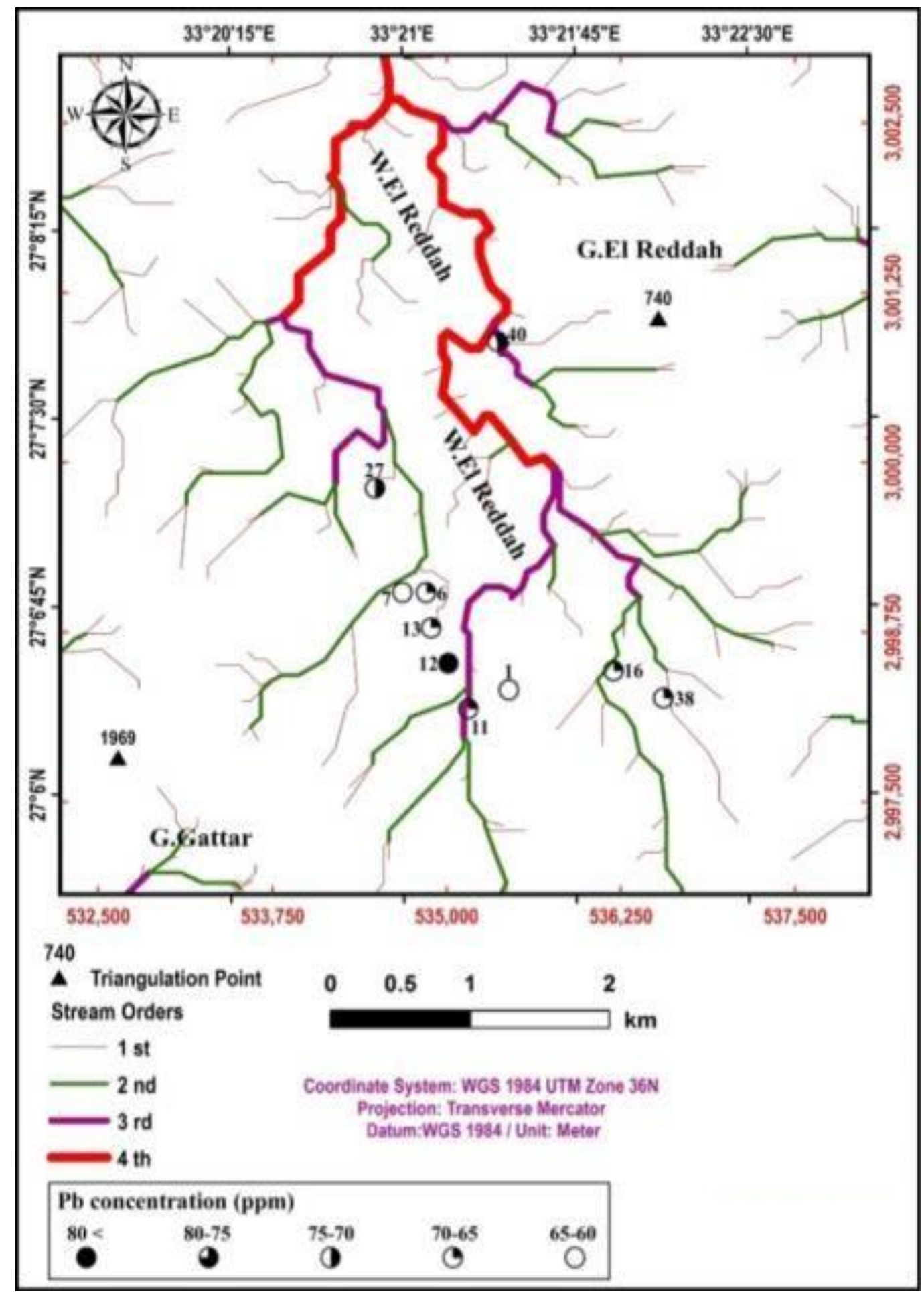

Figure 31. Geochemical map of $\mathrm{Pb}$ concentration (ppm) distribution in the stream sediments of Wadi El Reddah

Table 2. Clarke values for the indicator elements in stream sediments.

\begin{tabular}{|c|c|c|}
\hline \multirow{2}{*}{ Element } & Clarke values & Average values of elements in the study area \\
\cline { 3 - 3 } & & Stream sediment \\
\hline $\mathrm{Zr}$ & 200 & 471 \\
\hline $\mathrm{Rb}$ & 80 & 262 \\
\hline $\mathrm{Nb}$ & 10 & 167 \\
\hline $\mathrm{Zn}$ & 25 & 133 \\
\hline $\mathrm{Y}$ & 18 & 514 \\
\hline
\end{tabular}


Contents of trace elements range from 438.1 to 1117.9 ppm for total REE, Zr from 278 to 1215 ppm for $\mathrm{Zr}$, from 140.3 to $222.4 \mathrm{ppm}$ for $\mathrm{Nb}$, from 202 to $320 \mathrm{ppm}$ for $\mathrm{U}$, and from 246.8 to $305.2 \mathrm{ppm}$ for $\mathrm{Rb}$ (Table 1). These concentrations indicate the presence of valuable elements such as REE, U, Zr, and Y in the study area. Thorium (Th), zinc $(\mathrm{Zn})$, lead $(\mathrm{Pb})$, hafnium $(\mathrm{Hf})$, copper $(\mathrm{Cu})$, and arsenic (As) have low concentrations with mean values of 45.14, 132.9, 69, 48.6, 68.1, and 113.2 ppm, respectively.

\section{II.3. Correlation of Wadi El Reddah stream sediments with local and international stream samples}

Figure 4 shows the average trace elements concentrations for Wadi El Reddah compared with the average stream concentrations from other studies ${ }^{5-10}$. It is noticed that there is a distinct inter-basin variation where Y displays high contents at Wadi El Reddah stream sediment samples compared to the local and worldwide stream samples. The other elements have lower values than those of European, Gabal Hamra, and South Quseir sediments. The high $\mathrm{Pb}$ contents are mainly attributed to $\mathrm{Pb}$ minerals of stream sediments, including autunite, coronadite, and galena hosted by the surrounding granitic rocks of Gabal Gattar.

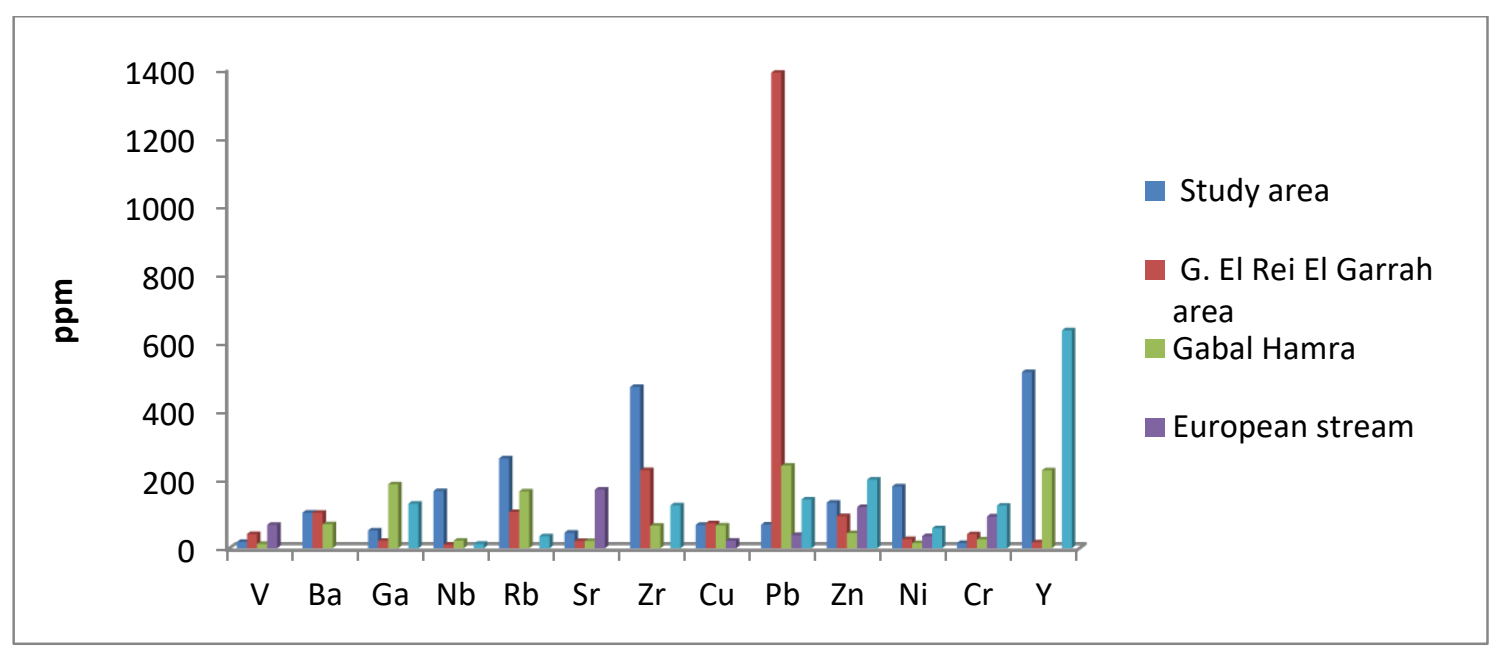

Figure 4. Presentation of the differences between the trace elements average of Wadi El Reddah and the other local and international stream sediment averages

\section{II.4. Multivariate Statistical Treatment}

\section{II.4.1. Correlation matrix}

The correlation matrices of some major oxides, trace, radioactive, and rare earth elements of the studied stream sediments are shown in Table 3.

Table 3. Correlation matrix for some major oxides and trace elements in the clastic rocks.

\begin{tabular}{|c|c|c|c|c|c|c|c|c|c|c|c|c|c|c|c|c|c|}
\hline & $\mathrm{Al}_{2} \mathrm{O}_{3}$ & $\mathrm{Fe}_{2} \mathrm{O}_{3}{ }^{\mathrm{t}}$ & $\mathrm{Ba}$ & $\mathrm{Sr}$ & $\mathrm{Li}$ & $\mathrm{Rb}$ & $\mathrm{Cs}$ & $\mathrm{Ga}$ & $\mathrm{Zr}$ & $\mathrm{Hf}$ & $\mathrm{Nb}$ & $\mathrm{Ta}$ & $\mathrm{Sc}$ & $\mathrm{Y}$ & $\mathrm{REE}^{\mathrm{t}}$ & $\mathrm{Th}$ & $\mathrm{U}$ \\
\hline $\mathrm{Al}_{2} \mathrm{O}_{3}$ & 1.00 & & & & & & & & & & & & & & & & \\
$\mathrm{Fe}_{2} \mathrm{O}_{3}{ }^{\mathrm{t}}$ & 0.41 & 1.00 & & & & & & & & & & & & & & & \\
$\mathrm{Ba}$ & 0.40 & 0.14 & 1.00 & & & & & & & & & & & & & & \\
$\mathrm{Sr}$ & 0.59 & 0.23 & 0.83 & 1.00 & & & & & & & & & & & & & \\
$\mathrm{Li}$ & 0.47 & 0.50 & 0.32 & 0.60 & 1.00 & & & & & & & & & & & & \\
$\mathrm{Rb}$ & 0.48 & 0.18 & 0.12 & 0.37 & 0.22 & 1.00 & & & & & & & & & & & \\
$\mathrm{Cs}$ & 0.41 & 0.13 & 0.21 & 0.49 & 0.24 & 0.96 & 1.00 & & & & & & & & & & \\
$\mathrm{Ga}$ & 0.78 & 0.55 & 0.46 & 0.44 & 0.37 & 0.63 & 0.47 & 1.00 & & & & & & & & & \\
$\mathrm{Zr}$ & 0.54 & 0.88 & 0.16 & 0.38 & 0.60 & 0.23 & 0.15 & 0.60 & 1.00 & & & & & & & & \\
$\mathrm{Hf}$ & 0.55 & 0.88 & 0.14 & 0.36 & 0.58 & 0.22 & 0.13 & 0.60 & 0.99 & 1.00 & & & & & & & \\
$\mathrm{Nb}$ & 0.54 & 0.91 & -0.02 & 0.23 & 0.54 & 0.50 & 0.41 & 0.64 & 0.89 & 0.83 & 1.00 & & & & & & \\
$\mathrm{Ta}$ & 0.42 & 0.79 & 0.07 & 0.22 & 0.37 & 0.68 & 0.62 & 0.66 & 0.65 & 0.64 & 0.90 & 1.00 & & & & & \\
$\mathrm{Sc}$ & 0.62 & 0.33 & 0.76 & 0.73 & 0.32 & 0.44 & 0.41 & 0.78 & 0.46 & 0.43 & 0.31 & 0.31 & 1.00 & & & & \\
$\mathrm{Y}$ & 0.64 & 0.56 & -0.16 & 0.21 & 0.53 & 0.61 & 0.49 & 0.61 & 0.69 & 0.67 & 0.80 & 0.63 & 0.39 & 1.00 & & & \\
$\mathrm{REE}$ & 0.59 & 0.93 & 0.29 & 0.38 & 0.55 & 0.13 & 0.05 & 0.66 & 0.95 & 0.95 & 0.84 & 0.63 & 0.53 & 0.60 & 1.00 & & \\
$\mathrm{Th}$ & 0.53 & 0.91 & 0.11 & 0.26 & 0.38 & 0.17 & 0.11 & 0.55 & 0.92 & 0.93 & 0.87 & 0.70 & 0.32 & 0.55 & 0.92 & 1.00 & \\
$\mathrm{U}$ & 0.48 & 0.14 & 0.31 & 0.51 & 0.22 & 0.18 & 0.15 & 0.37 & 0.48 & 0.46 & 0.18 & -0.06 & 0.70 & 0.46 & 0.42 & 0.28 & 1.00 \\
\hline
\end{tabular}


These matrices were calculated to define the interelement relationships in the stream sediment samples. A significant positive correlation is recognized between $\mathrm{Fe}_{2} \mathrm{O}_{3}{ }^{\mathrm{t}}$ and $\mathrm{Zr}$, Hf, Nb, Ta, REE, and Th, reflecting their close association within the stream sediments. A significant positive correlation is also observed between the following elements groups; $\left(\mathrm{Al}_{2} \mathrm{O}_{3}-\mathrm{Ga}\right),(\mathrm{Ba}-\mathrm{Sr}$ and $\mathrm{Sc}),(\mathrm{Rb}-\mathrm{Cs}),(\mathrm{Zr}-\mathrm{Hf}, \mathrm{Nb}$, REE, and Th), (Hf- Nb, REE, and Th), (Nb-Ta, Y, REE, and Th) and (REE-Th). Also recognized is somewhat moderate correlations between Sc-REE and $\mathrm{Sr} / \mathrm{Sc}-\mathrm{U}$, indicating $\mathrm{U}$ association with REE, Sc, and $\mathrm{Sr}$.

\section{II.4.2. Origin of the Stream Sediment and Mineralization}

The geochemical maps displaying $U$ enrichment corresponds well with REE, Y, $\mathrm{Zn}, \mathrm{Nb}$, and As anomalies in areas underlain by crystalline rocks to the north. Considering areas $>5 \mathrm{ppm} \mathrm{U}$ and $>15 \mathrm{ppm}$ Th as threshold9, more than $60 \%$ of the stream sediment sample results near Gabal Gattar and Gabal El Reddah point to areas favorable for $\mathrm{U}$ mineralization. We conclude that mineralization in this area is linked to deformation-induced radioelement remobilization and subsequent precipitation in veins forms.

\section{Discussion}

High sulfur contents indicate the role of chemical weathering by the effect of acidic solution in addition to the role of seawater and micro-organisms that lead to partial or complete dissolution of zircon crystals giving rise to new mineral associations (lowtemperature reaction forming low-temperature $\mathrm{U}$ mineralizations) and isomorphism between zircon, thorite, uranothorite and xenotime (high-temperature reactions). Also, the $\mathrm{w}$-shape of the REE pattern (tetrad effect) was detected in the REE pattern of the stream sediments ${ }^{10}$. The high contents of sulfide minerals (pyrite and sphalerite) in the stream sediments leads to high contents of $\mathrm{SO}^{3-}$ ion increasing acidity and enhance $\mathrm{Zr}, \mathrm{Hf}, \mathrm{Th}, \mathrm{U}$ and REEs leachability from the recorded mineral association.

The La/Y ratios are less than unity in all samples suggesting acidic environment. The presence of $\mathrm{Ce}$ positive anomaly and $\mathrm{Eu}$ negative anomaly indicates severe changes in the oxidation-reduction conditions that enhance low-temperature alteration processes. Oxidation-reduction conditions changes also occur by the effect of micro-organisms, indicating the presence of framboidal pyrite and biogenic sphalerite ${ }^{10}$.

The LREE are enriched in the stream sediments relative to the surrounding granitic rocks. Moreover, the nearly complete absence of monazite grains in the stream sediments and their presence in the surrounding hard rocks as indicated by petrographical and mineralogical studies might result from the complete dissolution of refractory monazite grains by low- temperature alteration processes. This presence of monazite and REEs as pore filling in the patchy parts of zircon and thorite grains and the presence of thorite inclusions in spherical apatite suggests the partial or complete dissolution of monazite. The complete isomorphism between xenotime, thorite, uranothorite, and zircon crystals are mostly observed in the studied stream sediments.

The non-chondritic $\mathrm{Y} / \mathrm{Ho}, \mathrm{Nb} / \mathrm{Ta}, \mathrm{Sr} / \mathrm{Eu}$, and U/Th ratios indicate the role of alteration processes in these unusual ratios. Role of seawater and hydrothermal alteration processes in the mobilization of major, trace, and REE elements. Therefore, physicochemical changes and micro-organisms play the main role in low-temperature alteration processes ${ }^{11}$.

The study area has high concentrations of REE, Y, Zn, $\mathrm{Nb}$, and As at the southern and eastern parts of W. El Reddah. The highest value of $\mathrm{Nb}$ in the south and east of W. El Reddah and the majority of quartz and feldspars might have been under the influence of granitic source rock from the domain area.

The correlations of radionuclides with major and trace elements show negative correlations with $226 \mathrm{Ra}(\mathrm{r}=$ $0.702, r=-0.672$, respectively), $232 \mathrm{Th}(\mathrm{r}=-0.621, \mathrm{r}=\mathrm{t}-$ 0.607 , respectively), and $210 \mathrm{~Pb}(\mathrm{r}=-0.615, \quad \mathrm{r}=$ 0.623 , respectively). On the other hand, 226Ra and $232 \mathrm{Th}$ are positively correlated with $\mathrm{Fe}(\mathrm{r}=0.615, \quad \mathrm{r}=$ 0.681 , respectively) and less significantly with $\mathrm{Mn}(\mathrm{r}=$ $0.570, \quad r=0.493$, respectively), indicating the association of these radionuclides with $\mathrm{Fe}$ and $\mathrm{Mn}$ oxides. Moreover, the positive correlations of $226 \mathrm{Ra}$ and $232 \mathrm{Th}$ with $\mathrm{Zn}(\mathrm{r}=0.589, \mathrm{r}=0.500$, respectively), $\mathrm{Cr}(\mathrm{r}=0.546, \mathrm{r}=0.578$, respectively), and $\mathrm{Ni} \quad(\mathrm{r}=$ $0.610, r=0.628$, respectively), also appear related with $\mathrm{Fe}$ and $\mathrm{Mn}$.

It is suggested that Gabal Gattar alkali feldspar granite, Gabal El Reddah monzogranite, and Hammamat sediments are the main sources of high contents of these elements upstream, in contrast to lower values downstream. This feature led to the discovery of new uranium, lead, and molybdenum mineralizations.

\section{Conclusions}

Geochemical distribution maps showed the role of chemical weathering in uranium migration from Gabal Gattar and Wadi El Reddah granites to the stream sediments. There is also a probability that $\mathrm{Sn}$, $\mathrm{Mo}, \mathrm{Au}$, and $\mathrm{Pb}$ mineralizations present in Gabal Gattar granite and the studied sediments. The Discovery of further U-occurrences in Gabal Gattar and Wadi El Reddah granites is a probability of increasing radioactivity around these peaks. Also, there is much evidence for finding REE and $U$ mineralizations within the vicinity of these peaks. There is also enough evidence for finding REE and $U$ mineralizations between basement rocks' contact at higher depths due to the change in $\mathrm{pH}$ conditions. 


\section{References}

1- H.V. Warren, R.E. Dellavault, Geochemical prospecting finds widespread application in British Colombia, Min. Eng., 1953, 5, 980-981.

2- B. Berg, M.P. Berg, P. Bottner, E. Box, A. Breymeyer, R. Calvo de Anta, M. Couteaux, A. Escudero, A. Gallardo, W. Kratz, M. Madeira, Litter mass loss rates in pine forests of Europe and eastern United States: some relationships with climate and litter quality, Biogeochemistry, 1993, 20, 127-159.

3- M.L. El Rakaiby, M.H. Shalaby, Geology of Gabal Gattar batholiths, central-eastern desert, Egypt. Int. j. Remote Sensing, 1988, 12, 2337-2347.

4- F.W. Clarke, The relative abundance of the chemical elements, Bulletin of the Philosophical Society of Washington, 1889, 135-143.

5- A. Levinson, Exploration Geochemistry, Applied Publishing, Wilmette, 1980.

6- L. Gromet, R. Dymek, L. Haskin, R. Korotev, The North American shale composite: its compilation, major and trace element characteristics, Geochim. Cosmochim. Acta, 1984, 48, 2469-2482.

7- R. Salminen, M.J. Batista, M. Bidovec, A. Demetriades, B. De Vivo, W. De Vos, M. Duris, A. Gilucis, V. Gregorauskiene, J. Halamic,
P. Heitzmann, Geochemical Atlas of Europe, Part 1 Background Information, Methodology and Maps, Geological Survey of Finland, Otamedia Oy, Espoo, 2005, 525.

8- K. Vrynioti, D. Alexakis, G. Bathrellos, H. Skilodimou, D. Vryniotis, E. Vassiliades, D. Gamvroula, Distribution of trace elements in stream sediments of Arta plain (western Hellas): The influence of geomorphological parameters, J. Geochem. Explor., 2013, 134, 17-26.

9- F. Ramadan, S. El Balakssy, O. Amer, Mineralogical and geochemical characteristics of the miocene-quaternary sedimentary formations, Wadi Wizr-Wadi Sharm El-Bahari Area, Central Eastern Desert, Egypt. Jour. Sediment., 2013, 82. 10-O.A. Ebyan, H.A. Khamis, A.R. Baghdady, M.G. El-Feky, N.S. Abed, Low-temperature alteration of uranium-thorium bearing minerals and its significance in neoformation of radioactive minerals in stream sediments of Wadi El-Reddah, North Eastern Desert, Egypt, Acta Geochim., 2020, 39, 96-115.

11-S.J. Ekwere, Li, F and Rb contents and $\mathrm{Ba} / \mathrm{Rb}$ and $\mathrm{Rb} / \mathrm{Sr}$ ratios as indicators of post-magmatic alteration and mineralization in the granitic rocks of the Banke and Ririwai younger granite complexes, North Nigeria, Mineral. Deposita, 1985, 20, 89-93. 